\title{
Research on the Cultivation Path of Vocational Quality of Vocational College Students
}

\author{
Xiaochun Shi \\ Dalian Vocational \& Technical College \\ Dalian, China
}

\begin{abstract}
The cultivation of vocational quality is an important part of the training of higher vocational talents. Higher vocational college can strengthen students' qualities by combining with its own characteristics through vocational ethics education, career planning, vocational skills training, employment guidance and other paths.
\end{abstract}

Keywords-vocational college students; vocational quality cultivation

\section{INTRODUCTION}

Any vocation has certain requirements on the quality of people. It not only includes the qualities that should be possessed in a particular vocation, but also the potential to achieve these qualities. Therefore, vocational quality is the basis of a person's vocational activities, the cornerstone of a successful career, the foundation of the workplace, and the development of a person's career. It is the quality that every vocational college student and practitioner should possess.

\section{THE CONNOTATION AND SIGNIFICANCE OF VOCATIONAL QUALITY}

\section{A. The Connotation of Vocational Quality}

Vocational quality consists of two parts, namely, vocation and quality. In short, it refers to a specific quality that meets the needs of a vocation. Vocational quality refers to the inner basic quality that laborers form and develop through professional (vocational) education (training), professional practice and self-improvement on the basis of physical and psychological conditions and plays an important role in vocational activities. It mainly includes vocational ethics, vocational awareness, vocational knowledge, vocational skills, vocational psychology, and vocational image, etc.

The vocational quality cultivation of vocational college students is of great significance to the career of higher vocational college students, to the development of modern enterprises, and to the reform of higher vocational colleges. Therefore, as a vocational college, it is necessary to regard the cultivation of students' vocational quality as equal status to education and teaching in treating.

\section{BASIC REQUIREMENTS FOR VOCATIONAL QUALITY EDUCATION IN HIGHER VOCATIONAL COLLEGE}

\section{A. Staged, Focused, and Full-scale Implementation of} Vocational Quality Education Throughout Three Years in Higher Vocational College

Higher vocational college should penetrate and infiltrate the whole process of three-year college education. It is necessary to systematically design the talent cultivation program, to achieve comprehensive planning, overall arrangement, cooperation division and overall promotion in order to ensure students' comprehensive health development. According to the characters of vocational students, vocational quality education activities are divided into three stages: adaptation transition, gradual development and comprehensive improvement, and employment preparation. The vocational quality education runs through the whole process of students' study in college.

\section{B. Vocational Quality Cultivation Methods Should Be Diversified}

It is necessary to establish a vocational quality activity system and carry out a variety of activities, such as amateur party school learning, public service type student volunteer service activities, political theory debates, ideological and political activities, summer social practice activities and so on for the cultivation of vocational ethics; such as various science and technology festivals, vocational practice, skill competitions, student entrepreneurship activities, employment lectures, student club activities based on vocational ability, corporate visits, practice activities and so on for the cultivation of vocational skills and vocational spirits. Incorporating vocational-related training content into the activity can promote the vocational quality education activities to be carried out more effectively.

\section{Vocational Quality Education Needs the Integration of the First Class, the Second Class and the Third Class}

The ways of vocational quality education in colleges and universities mainly include the first class in the form of class teaching, the second class in the form of community activities, scientific and technological cultural activities, and the third class in the form of social practice, off-campus visits, and internships. The first class is the foundation, and the second and third classes are the expansion and extension 
of the first class. It is necessary to deepen the coordination mechanism between the first class and the second and third classes.

Making full use of social and enterprise resources and strengthen practical links.

In the process of vocational quality education, we must pay attention to actively attract social resources and enterprise participation. It is necessary to break the closed school-running mode, organize students to enter the enterprise, enter the society to participate in practice and internship, raise awareness and enhance their abilities in practice and internship. At the same time, the college should also invite. The college can hire professional human resources experts from the society to conduct self-assessment, career planning and image design. Successful people, entrepreneurs, and excellent alumni can also be invited to give lectures for students, provide career counseling services, enhance self-confidence in job search, and improve students' motivation.

\section{The Path of Vocational Quality Cultivation}

The vocational quality cultivation for vocational college students mainly includes the following aspects: vocational ethics education, career planning, vocational skills training, and employment guidance.

\section{A. Conduct Vocationalethics Education}

1) Defining the industry ethics content that students should have: Each industry has different job nature, social responsibility, service targets and service means. Each industry has its own specific industry vocational ethics, and the focus of each line for vocational ethics is also different. Through the analysis of vocational positions, the college can help students to define the content of vocational ethics in vocational positions and carry out corresponding activities or education in a planned manner.

2) The content of vocational ethics throughout the three years of vocational teaching: In the process of teaching, professional teachers must infiltrate vocational ethics into daily education and teaching, and exert subtle influence on students. By combining students' vocational courses, the teachers should carry out targeted vocational ethics education, and explain to students the vocational ideals, vocational ethics, vocational discipline, etc. At the same time, the teachers can combine the development history of the major to enumerate the actions of outstanding people in the vocational field and the dedication spirit shown by them to consciously infiltrate vocational ethics education.

3) The second class carries out vocational ethics campus cultural activities: In the three years of students' college life, the campus culture activities of the second class focus on the development of vocational ethics, and vigorously promote vocational ethics education through network, radio, newspapers, and bulletin boards; entrepreneurs' experience exchange on vocational ethics to stimulate students' awareness of dedication, hard work, and entrepreneurship; developing civilized class collectives, civilized dormitory creation activities, integrating vocational ethics education into daily activities; carrying out vocational ethics education as the theme of activities such as theme class meetings, essay competitions, reading competitions, speech competitions, debate competitions, photography competitions, etc., thus making students participate and gain experience.

4) Being strict with students' daily management and developing habits: The moral cognition is not enough for vocational ethics. It is necessary to guide students to develop ethical behavior habits that meet the needs of the vocation on the basis of understanding the vocational ethics, and the practice training of behavioral habits is indispensable.

It's necessary to take the daily life of the students as a starting point to cultivate students' good behavior habits, focus on students' classroom behavior, apartment behavior and campus behavior, and ask students to start from themselves, start from their own side, start from now, start from behavioral norms, and start from behavioral habits training to overcome some bad behavior habits. As time passes, it will develop good behavior habits and cultivate students' rule consciousness, responsibility consciousness and civilized behavior.

5) Paying attention to the influence of teachers' professional quality on the subtle influence of students' vocational ethics education: Teachers are the models. Teachers' professional ideals, professional attitudes, professional duties, professional skills, professional discipline, professional conscience, professional honor and professional role are in the subtle influence on students, and higher vocational college students are facing the reconstruction and perfection of personality. In this critical period, the quality and image of teachers often have a profound impact on them.

6) Making full use of practice and internships to enhance practical opportunities: The development of vocational ethics can only be realized in edification of the environment and practice of the vocational ethics. It is necessary to make full use of various rich and varied practical and internship links in the teaching process, such as taking students to the cooperation enterprises to visit and practice experience, providing vocational ethics education for students; organizing various practical activities and volunteer services in the second class; building shared training base with enterprises for students to participate in the real business while they are in school, and providing vocational ethics education to students in the process.

\section{B. Conducting Career Planning Education}

1) Improving students' understanding of career planning from the introduction of new majors: In the first lesson of new students' entrance education, we must do majors introduction to help students to understand the professional talent training objectives and curriculum 
settings. On this basis, we will refine the vocational job categories and quality and ability requirements to make students think about their career development issues as soon as they enter school, and establish correct values, outlook on life, and employment view.

2) Opening a career planning course: It's necessary to incorporate Career Planning for College Students as a compulsory course into the teaching plan. Through the study of career planning courses, all students fully grasp the theory of career planning, master the methods of career planning, improve students' ability to make career choices, and guide each student to actively and rationally plan their career.

3) Conducting vocational evaluation to help students understand themselves: The process of helping students to develop career planning is a process that allows students to discover themselves, recognize themselves, and tap their potential. Therefore, the first thing to do is to evaluate the self and carry out vocational evaluation. For example, many schools have introduced the talent evaluation system of Beisen Company to help students understand their personality characteristics and do their own career planning.

4) Professional tutors carry out "one-on-one" career counseling: The college sets up a career tutor for each student who is responsible for three years of career planning and career guidance. Each tutor is responsible for more than a dozen students to each grade. The main responsibility of the professional tutors is to guide freshmen to correctly understand themselves and establish their own career ideals. According to the performance of the sophomore students in the implementation plan for one year, they will talk with each student, summarize the results and point out the insufficiency, and guide students to modify their career plans according to their actual situation; advise students on job interviews for juniors, provide guidance on students' resume making, interview skills, etc., and provide employment counseling services for students; when the students enter the internship position, the professional tutor will also follow up to answer questions and help students adapt to the post requirements as soon as possible.

\section{Conducting Systematic and Targeted Employment Guidance}

The employment guidance will start until the students are close to employment. It is necessary to run through three years of education. In the process of enrollment education for freshman, it is necessary to let students have a vision for the future career through majors' introduction, expert lectures, etc., and have a position on the advantages of their higher vocational colleges, majors' prospects and their own. After that, through lectures, activities and various other forms, we should give professional guidance that will help students to understand the career prospects of their majors and the development trend of the industries in order to make their study in colleges more objective and directional. From the second semester of the sophomore year, we should carry out a variety of employment guidance lectures, such as social etiquette lectures, mock interviews, resume contests and other activities to help students master certain interview and job search skills, so that they can have a stable attitude and consummate skill in employment to improve employability.

\section{Paying Great Attention to the Cultivation of Vocational Skills}

The advantages and disadvantages of vocational skills training in higher vocational colleges are related to the employment of students in higher vocational colleges and the long-term sustainable development of colleges. It is not enough to improve the vocational skills of students simply by classroom teaching. It requires a lot of spare time training and practice.

1) Focusing on publicity and education in order to make students fully understand the growth path of their professional skills: When students first enter the colleges, most of the students' ideological understanding still stays in the high school stage. They think that there will be no problems as long as they study the knowledge carefully. In this case, the college should not only explain the three-year knowledge goal to the students in the process of majors' introduction clearly but also describe in detail the three-year skill goals and cultivation paths for students to make students truly realize the importance of vocational skills to vocational college students, which it is more important. The college can mobilize the enthusiasm and initiative of students to develop vocational skills through the promotion of the entire vocational skills improvement project, the summary of vocational skills improvement in the previous year, and the recognition and reward of outstanding students.

2) Establishing a professional student association to normalize vocational skills training: The traditional associations are set up to enrich students' extracurriculum cultural life, mainly in hobbies. The secondary colleges can set up professional associations according to their majors. Each student participates in a professional association according to the hobbies and development directions. The professional associations are responsible for the secondary colleges. The secretary of the Youth League Committee is responsible for the daily activities and management of the secondary associations. Each professional association employs professional teachers as the tutors. The main content of the activities is vocational skills training. The professional association is guided by a full-time teacher to guide the daily activities. The backbone of the senior students as the "little tutors" is responsible for the organization and development of the activities.

3) Relying on the vocational skills competition to achieve the goal of "promoting learning by competition, promoting teaching by competition, and promoting training by competition": The vocational skill competition is not only a test of the quality of vocational education and the level of running a school, but also an important means to promote vocational colleges to deepen teaching reform, 
strengthen school-enterprise cooperation, and promote the integration of engineering and learning. Higher vocational college can carry out relevant vocational skill competitions according to the majors' characteristics of the college. It can not only stimulate students' interest in learning and motivation, but also help to consolidate students' theoretical knowledge, exercise students' practical ability, cultivate students' awareness of pioneering spirit, teamwork and the ability to improvise, and enhance students' professional ability, professional quality and humanistic quality.

In order to achieve the goal of "promoting learning by competition, promoting teaching by competition, and promoting training by competition", vocational colleges can practice and explore from the following aspects:

First, organize students to participate in various competitions, and promote the training by competition

Each year, the college holds a college vocational skill competition to encourage students' enthusiasm for participation and create an atmosphere of "everyone can participate and everyone must participate". On the basis of the college competition, the students can participate in provincial, municipal and national competitions after a series of selections. Through the full preparation of professional teachers and participating students and carefully summing up the experience, the students' professional skills are getting higher and higher, and the results will be better and better.

Second, establish vocational skill competition management system for standardizing secondary vocational colleges

In order to ensure the smooth organization and operation of the competition, the secondary management system is established for schools and colleges. The college should establish a vocational skill appraisal center, which is mainly responsible for the review, organization, operation, coordination and control of each competition project. The secondary colleges set up a leading group for vocational skill competitions. They are composed of the party and government leading group, the secretary of the Youth League Committee and the directors of every major. They are responsible for the declaration, promotion, organization and evaluation of specific projects, and coordinate and determine the time and publicity of each project competition. Each major organizes the competition project declared according to the characteristics of the major and the subject and the different requirements of the students' ability. The goal for the content and form of the project is to strengthen the training of students' vocational skills, strengthen the comprehensive application ability investigation, and mobilize students' interest in learning and subjective initiative. We should give emphasis on the practicality and innovation of the project, and strive to create a new practice platform for students.

Third, break the traditional evaluation system and reform the scholarship system

In order to motivate students to improve their vocational skills, in addition to the prizes or awards given by the college itself, the college should make comprehensive improvement in the evaluation of awards, and amply reward vocational skills scholarships based on the scholarships at the national, provincial, municipal and college levels. At the same time, in the honorary title, we should establish the title of "vocational skill expert", and commend students who have special skills or outstanding achievements in vocational skills.

Fourth, bring in, go out, and connect with society and enterprises.

The integration of production and education is the core feature of running a higher vocational college. The college should strive to bring in, go out, and connect with society and enterprises. The college should be in contact with the enterprise, the school and enterprise cooperate to carry out the vocational skill competition, and use the real business of the enterprise as the content of the competition to improve the students' skills through competition.

Fifth, pay attention to the students' mentoring and give full play to the main role of the students.

The cultivation of skills is a step-by-step training process. Students must make full use of their spare time to practice. It is difficult for full-time teachers to be with students in time. Therefore, it is necessary to fully mobilize students' initiative and consciousness through full-time teachers cultivating senior students as "little teachers", they will lead the students to practice and prepare for the competition to achieve the effect of mentoring, and also improve the students' learning ability.

4) Interconnecting with industry and enterprises to enable students to get in touch with real business during their school days: Higher vocational colleges should take the initiative to contact enterprises, establish practice bases, and organize students to enter the practice base to visit and practice. The skill-based practice base for urgently-needed talents with the "professional and real" features, it has both practical teaching and vocational quality training functions, as well as skills training functions. Under the guidance of the enterprise, the teachers lead the students to deal with the business, so that students can have real business skills without leaving the school.

\section{CONCLUSION}

The vocational quality cultivation for vocational college students is a comprehensive and systematic project. In addition to the vocational education in the first class, the four aspects of vocational ethics education, career planning, vocational skills training and employment guidance in the second class is an important path for the cultivation of students' vocational quality. Higher vocational colleges can effectively improve the vocational quality of students through the design of scientific planning system. 


\section{REFERENCES}

[1] Guo Huiling,Discussion on Ways to Strengthen Vocational Quality Education in Higher Vocational Colleges, Journal of Guizhou Commercial College, 2006.9 (in Chinese)

[2] Nie Ying,Analysis of the Vocational Quality Education of Students in Higher Vocational Colleges in China,Tianjin University, China, 2009.3 (in Chinese) 